\title{
Pendidikan Karakter Berbasis N ilai Ahlussunnah Waljamaah (Studi Kasus di MTs Ma'arif NU Kemiri, Purworejo)
}

\author{
U an Abdul H anan \\ ST AIN U Purworejo, Indonesia
}

uanahanan@gmail.com

\begin{abstract}
Character education is important in Indonesia, to answer the problem of worrying national character. Among nahdliyin character education is based on the values of ahlussunnah waljamaah. Research on M Ts Ma'arif NU Kemiri Purworejo is intended to reveal the application of aswaja values in character education to students. This field research is qualitative by using observation, interview documentation in data collection and Habermens theory for data analysis. The results of the study found that the cultivation of aswaja values (tawassuth, itidal, tasammuh, ishlahiyyah and tathowwur) was carried out thoroughly from planning, implementation and evaluation. Character education based on ahlussunnah waljamaah values is carried out sequentially through habituation strategies, introduction of knowledge of goodness, introduction of love of virtue, uswah hasanah, and academic and non-academic repentance.
\end{abstract}

Keywords: Character education, value internalization, A hlussunnah Waljamaah

\begin{abstract}
Abstrak
Pendidikan karakter penting di Indonesia, untuk menjawab persoalan karakter bangsa yang memprihatinkan. Di kalangan nahdliyin pendidikan karakter itu berbasis nilainilai ahlussunnah waljamaah. Penelitian terhadap MTs Ma'arif NU Kemiri Purworejo ditujukan untuk mengungkap penerapan nilai aswaja dalam pendidikan karakter pada siswanya. Penelitian lapanagan ini bersifat kualitatif dengan menggunakan observasi, wawancara dokumentasi dalam pengumpulan datanya dengan teori $\mathrm{H}$ abermens untuk analisis datanya. Hasil penelitian menemukan bahwa Penanaman nilai aswaja (tawassuth, i'tidal, tasammuh, ishlahiyyah dan tathowwur) dilaksanakan secara menyeluruh sejak perencanaan, pelaksanaan dan evaluasi. Pendidikan karakter berbasis nilai ahlussunnah waljamaah dilaksanakan seacara berurutan melalui strategi pembiasaan, pengenalan pengetahuan kebaikan, pengenalan kecintaan pada kebajikan, uswah hasanah, dan pertobatan akademik maupun non akademik)
\end{abstract}

Kata kunci: Pendidikan karakter, internalisasi nilai, Ahlussunnah Waljamaah 


\section{A. Pendahuluan}

Karakter yang memprihantinkan masih kerap kita jumpai di tengah masyarakat khususnya remaja usia sekolah. Krisis moral pada dunia pendidikan menjadi persoalan yang mengganggu pendidikan karakter itu sendiri dan sekaligus sebagai obyek dari pendidikan karakter. Padahal, moral sebagai aturan yang mengatur tindakan atau perilaku seseorang sebenarnya dapat dikondisikan melalui pendidikan untuk mengetahui mana yang baik dan benar, sehingga diharapkan tidak terjadi penyimpangan perilaku.

Laporan Kompasiana menyebutkan bahwa ada dua perilaku menyimpang yang dilakukan oleh murid terhadap gurunya, yakni: Pertama, kasus murid menyawer gurunya, kedua. Kasus murid melawan guru saat ditegur (Pangwijaya, 2019). Keduanya merupakan prilaku yang muncul dari karakter yang salah pada anak remaja di sekolah, tidak ada penghormatan kepada orang yang selama ini harus dihormati. Kasus lain adalah AY di Kalimantan, seorang siswi SM P yang menjadi korban pengeroyokan oleh siswi SM A. Aksi tersebut dilakukan pada jumat $29 \mathrm{M}$ aret 2019 di sebuah bangunan di Pontianak Kalimantan Barat ( Ambarwati, 2019). Perilaku ini menunjukkan tidak adanya pemahaman yang baik pada siswa tentang perilaku yang baik dan yang seharusnya dilakukan, yakni menyanyangi mereka yang lebih muda, bukan sebaliknya mengeroyok dan memaksakan kehendak kepada mereka. Laporan KPAI di tahun 2019 ada 153 aduan kekerasan fisik terhadap siswa. 153 kasus terdiri dari korban kebijakan, anak korban kekerasan fisik dan bulying (Siska N irmala, 2019). Kasus ini tidak mewakili keseluruhan kasus yang ada pada siswa di Indonesia, karena sebagian besar tidak diadukan kepada KPAI atau pihak lain yang berwenang. Kasus lainnya adalah tawuran pelajar di Bogor tanggal 100 ktober yang lalu. Akibat dari tawuran ini, menimbulkan satu korban jiwa. Ini merupakan persoalan serius dari karakter pelajar kita (J uli H antoro, 2021).

Sederet prilaku dan kekerasan tersebut menunjukkan persoalan karakter siswa yang patut mendapat perhatian dalam pendidikan karakter. Sejauh mana upaya pendidikan yang seharusnya memberikan jawaban atas persoalan tersebut. Pendidikan Agama Islam atau lembaga yang berbasis pada pendidikan agama Islam memiliki tanggung jawab yang besar untuk menjawabnya. Pendidikan karakter memiliki pengaruh yang kuat dalam pembentukan karakter bangsa yang dalam bahasa lain disebut akhlak al-karimah. Pelaksanan pendidikan karakter membutuhkan proses pendidikan nilai-nilai atau kebajikan, di mana nilai-nilai dan kebajikan tersebut merupakan nilai dasar karakter suatu bangsa.

Dengan demikian, pendidikan karakter pada hakekatnya adalah pengembangan nilainilai yang berasal dari pandangan hidup bangsa Indonesia, agama, budaya (Syamsul, 2013), 
dan nilai-nilai yang terumuskan dalam tujuan pendidikan $N$ asional (Zubaedi, 2011) Ada sembilan pilar karakter yangberasal dari nilai-nilai luhur, yakni cinta Tuhan dan ciptaanya, mandiri dan tanggungjawab, kejujuran dan amanah, diplomatis, hormat dan santun, dermawan, suka menlong dan kerjasama, percaya diri dan bekerja keras, kepemimpinan dan keadilan, baik dan rendah hati, serta toleransi atas kedamaian dan kesatuan. (Zubaedi, 2011). Sementara itu, Kemendiknas dalam publikasi ilmiahnya berjudul Pedoman Pelaksanaan Pendidikan Karakter mengidentifikasi ada 18 karakter yang dibutuhkan dalam pendidikan disamping yang telah diemukakan dengan tambahan kratif, demokratis, rasa ingin tahu, semangat kebangsaan, cinta tanah air, gemar membaca, peduli lingkungan dan peduli sosial (Penyusun, 2011)

Istilah Pendidikan karakter mulai marak berkembang pada saat kurikulum 13 diterapkan di Indonesia. Semangat pendidikan karakter pada kurikulum 13 menjadi rujukan beberapa lembaga dalam mengembangkan kurikulumnya. Ini pula yang mendasari Lembaga pendidikan yang berbasis agama di Indonesia melaksakan pendidikan karakter sebagai bagian dari kepedulian mereka terhadap keprihatinan karakter bangsa. Lembaga pendidikan maarif yang bernaung di bawah $\mathrm{N}$ ahdlatul Ulama (NU) pada awal tahun 2014 mulai menyiapkan sekolah/madrasah unggul yang berbasis Ahlussunnah Waljamaah. Semangat itu semakin kuat setelah rapat pleno LP M aarif NU tahun 2014 yang menghasilkan 9 point-point penting meliput: implemtasi program pendidikan $\mathrm{N} U$, membangun web-best system, memfungsikan badan hukum pendidikan, penetapan standar penjaminan mutu, kurkulum Aswaja, kaderisasi aswaja, implemtasikan kurikum 13, penguatan litbang dan kerjasama dengan pemerintah (H idayah, 2015)

Isu kurikulum 13 yang berbasis pada pendidikan karakter sudah mulai bergeser. T etapi nilai-nilai karakter sebagai bagian yang harus tetap ada dalam pembangunan karakter bangsa tetap melakat. N ilai-nilai Ahlussunnah W aljamaah di lembaga lingkungan nahdliyyin, menjadi dasar nilai pendidikan karakter yang akan diajarkan dalam pendidikan karakter di Sekolah/M adrasah U ngulan M aarif NU. N amun, sejauh mana nilai A hlussunnah Waljamaah terumuskan, dan bagaimana pendidikan karakter dapat diimplementasikan dalam proses pendidikan di lembaga Ma'arif. Penelitian ini bertujuan untuk mengetahui Bagaimana strategi pendidikan karakter berbasis nilai-nilai Ahlussunnah Waljamaah diterapkan di MTs Ma'arif NU Kemiri Purworejo sebagai bagian dari lembaga pendidikan Ma’arif yang melaksanakan pendidikan karakter berbasis ahlussunnah waljamaah.

Beberapa penelitian terdahulu yang pernah dilakukan terhadap sekolah atau madrasah yang menerapkan pendidikan karakter berbasis nilai ahlussunnah antara lain: pertama. 
Penelitian Subaidi, menjelaskan tentang hubungan pendidikan karakter berbasis aswaja dengan karakter kebangsaan dan cinta tanah. Keduanya memeiliki keselarasan dalam pengembangan masing-masing karakter. Siswa di Madrasah Aliyah Amtsilati Bangsri disamping memlikikarakter berbasis aswaja juga karakter kebangsaan, yaitu cara berfikir, bertindah dan berwawasan yang menempatkan kepentingan bangsa dan negara di atas kepentingan diri dan kelompoknya. (Subaidi, 2019)

Kedua, Penelitian Faris K hoirul Anam, M oh Fadil dan mU khammad Yahya. Penelitian memberikan tawaran rumusan nilai kakter aswaja a-nahdliyah dalam memperkokoh moderasi beragama di Pondok Pesantren. H asil penelitian terhadap semua unsur dalam boarding school menunjukkan perlu penguatan materi aswaja dalam pembentukan karakter aswaja karena adanya sekat pemisah antara fikih dan akidah. Aswaja dapat dijadikan sumber dalam pengembangan kurikulum yang mengarah pada moderasi beragama. (Anam et al., 2021)

Ketiga, Amin Ary Wibowo, Ma'mun E Nur dan Muslih Abdul Karim. Penelitian literatur ini menjelaskan bahwa nilai-nilai aswaja dapat dijadikan modal penting untuk membangun pemahaman keagamaan yang moderat. Dan pendidikan menjadi pilihan utama dalam memproses karakter berbasis nilai aswaja ini sebagai pedoman kehidupanya. $\mathrm{N}$ ilai-nilai aswaja juga dapat dimasukkan ke dalam materi pembelajaran dan proses pendidikan untuk mendukung lahirnya pemahaman, pola sikap dan tindakan yang moderat dalam beragama. (Wibowo et al., 2018)

Ketiga penelitian tersebut berbeda dengan penulis dalam sasaran penelitian. Penulis menitik beratkan penelitian pada strategi penerapan pendidikan karakter berbasis nilai ahlussunnah waljamaah yang dilaksanakan oleh madrasah dalam berbagai tahapan-tahapanya, serta mengamati program madrasah, baik yang muncul dalam kurikulum maupun hiden kurikulum. Penelitian ini merupakan penelitian kualitatif yang menggali hakekat yang ada dalam pelaksanaan pendidikan karakter di MTs Ma'arif NU Kemiri, Purworejo. Sumber Penelitian menggunakan teknik purposive sampling dengan tehnik penglumpulan data melalui O bservasi, wawancara dan dokumentasi. A nalisi data meliputi reduksi data, penyajian data dan penarikan kesimpulan

\section{B. Pembahasan}

\section{Pendidikan Karakter Berbasis nilai-nilai Ahlussunnah waljamaah}

Karakter dalam bahasa Indonesia berasal dari bahasa Latin dengan asal kata "kharakter", "kharassein", "kharras" yang artinya membuat tajam dan membuat dalam 
(Andayani, 2011). Secara etimologis, kata karakter berasal dari bahasa Yunani Charrassein yang berarti membuat tajam, membuat dalam (Abdulloh, 2017). Istilah karakter memiliki beberapa pengertian, antara lain karakter dimaknai sebagai cara berfikir dan berperilaku yang khas dari individu untuk hidup dan bekerja sama, baik dalam lingkup keluarga, masyarakat, bangsa dan negara. Karakter adalah nilai-nilai perilaku manusia yang merupakan hasil dari interaksi dirinya dengan lingkungan yang ada di sekitarnya baik berupa fisik, rasa, norma, hukum, agama, maupun ide dan pemikiran secara individual maupun kolektif, sehingga merupakan perilaku yang tampak dari seseorang dalam bertindak maupun bersikap (H ariyanto, 2011). Karakter dikenalkan sebagai "a system of stiving wich underlines behaviour", karakter adalah alasan-alasan, motivasi yang disadari atau tidak, mengapa seseorang melakukan tindakan-tindakan tertentu (Amirudin Yoyok, 2017).

Pendidikan karakter berarti suatu usaha berkelanjutan yang diarahkan pada pembentukan karakter yang dilandasi nilai-nilai luhur yang bersumber dari lingkungan, agama, norma sosial, tujuan negara dan idealita kemanusiaan untuk mengembangkan potensinya menjadi manusia dewasa yang memiliki martabat yang tinggi. Pendidikan karakter bersifat menolong pengembangan potensi manusia menuju kepemilikan karakter yang baik. Pendidikan karakter dengan demikian memiliki peran yang besar dalam ikut mempengaruhi perubahan karakter yang akan dimiliki seseorang melalui usaha sadar yang dilaukan orang dewasa menuju ke arah pembentukan karakter baru yang baik. Pendidikan karakter merupakan usaha yang dilakukan secara sengaja untuk membantu seseorang agar mampu memahami, memperhatikan dan melakukan nilai-nilai etika yang inti. ( Lickona T homas, 2015)

Prinsip pendidikan karakter yang dipersamakan dengan pendidikan akhlak diarahkan pada pembentukan akhlak yang baik. Tujuan Pendidikan karakter untuk membentuk kepribadian anak ke arah yang lebih baik sebagai manusia, warga masyarakat dan warga negara yang baik ( $H$ eri, 2012). Proses pendidikan pada anak didik diproyeksikan untuk membangun hati nurani agar setiap anak didik memiliki kepekaan dan pengahayatan atas nilai-nilai luhur. Referensi kebaikan akhlak disandarkan pada tata nilai yang menjadi kesepakatan bersama dalam suatu komunitas, masyarakat maupun negara dan kemanusiaan.Fakhrur razi dalam disertasinya mengutip pandangan J eynes bahwa tujuan uta pendidikan adalah membantu anak menjadi pintar, cerdas, mengembangkan potensinya dan membentuk menjadi baik, penih sayang dan disiplin (Fatkhur, 2019).

Adapun istilah ahlussunnah waljamaah tidak lepas dari hadits Iftiroqu U mmah (W. A. M uhammad, 2012). H adits ini menyebutkan bahwa umat Islam pada masa-masa mendatang berpecahan menjadi 73 golongan, hanya satu yang selamat, yakni firqotun najiyah dan 
golongan inilah yang masuk surga. Hadits-hadits firqutun najiyah mengandung tiga term yang disimpulkan oleh U lama menjadi Ahlussunnah Waljamaah, yakni, ma ana 'alaihi wa ashhabihi, al-jamaah dan as-sawadul a'dhom. Ketiga term ini menurut Abu Muhammad Waskito, berdasarkan kesimpulan Syekh Salman al-Audah tentang hadits-hadits firqotun najiyah bahwa ciri Ahlus as-sunnah wa al-jama'ah adalah adanya Jamaah sebagaimana hadits Muawiyah, Auf bin M alik dan anas; M engikuti aku dan shabatku, sebagaiman hadits Abdullah bin amr bin ash dan Anas; serta Kelompok yang besar, sebagaimana tersebut dalam hadits Jabir dan Abu U mamah (W. A. M uhammad, 2012)

Dalam tinjauan bahasa. Ahlussunnah terdiri dari tiga kata, yaitu: (1) Ahl. Bahasa Arab: ahli, ahala, ya' halu, atau ya'hilu, uhulan berarti: penghuni sebuah tempat, suami, istri, kerabat, dan bisa juga bermakna pengikut (Purna Siswa Aliyah, 2007). (2) As-sunnah. Bahasa Arab yang berarti suatu sarana, suatu jalan, aturan, dan cara untuk berbuat atau cara untuk hidup, dan metode atau contoh. D alam arti aslinya, as-sunnah menunjuk pada perkataan, perbuatan dan persetujuan yang berasal dari N abi Saw (A. M uhammad, 2011). (3) Al-Jama'ah, berasal dari kata jama'ah: mengumpulkan sesuatu, merupakan lawan kata dari tafarruq (perceraian) dan furqah (perpecahan). Jama'ah adalah sekelompok orang banyak, berarti juga kaum yang bersepakat dalam suatu masalah.Jama'ah ini merupakan kelompok mayoritas, memiliki arti sama dengan as-sawadul a'dhom. Kata al-Jama'ah bukan kelompok ataupun aliran, melainkan Jama'ah yang dimaksud disini ialah orang-orang yang telah mengamalkan ilmunya, dengan tujuan agar selamat di dunia dan akhirat.

Munculnya istilah Ahlussunnah Waljamaah merupakan alternatif dari perdebatan antara qadiriyah, jabariyah dan mu'tazilah (Ari, 2019). Dalam konteks ke-Indonesiaan, ajaran Ahlussunnah Waljamaah didasarkan pada pengertian Ahlussunnah Waljamaah itu sendiri, yakni: sekelompok orang yang secara terus menerus melaksanakan sunnah $\mathrm{N}$ abi M uhammad SAW dan sahabat Nabi SAW dalam semua bidang kehidupan, meliputi: bidang akidah (tauhid), amaliyah badaniyah (syari'ah) dan etika moral ( tasawuf) (Abdusysyukur, n.d.)

N ilai-nilai Ahlussunnah Waljamaah, yaitu: moderat, adil, toleran, dan Sikap reformatif dan dinamis dapat dijabarkan sebagai berikut: Pertama, nilai sedang ( Al-Tawassuth) adalah berprilaku mencari jalan tengah, bersikap rata-rata, tidak berlebihan dalam menunjukkan sikapnya, baik menyikapi sesuatu yang baik maupun yang buruk. Dikenal dengan sikap moderat sebagaimana firman Allah dalam al-quran surat al-Baqarah ayat 143. Prinsip-prinsip yang dipilih antara lain: (1). al-Shidqu (kebenaran, kejujuran), (2). al-Amanah (dapat dipercaya), (3). al-Ta'awun (kerjasama), (4). al-'Adalah (adil), dan (5). al-Istiqamah (konsistensi); Kedua, N ilai wajar ( al-I'tidal) merupakan skala sikap seseorang terhadap segala 
sesuatu secara proporsional, menempatkan sesuatu pada tempatnya. bersikap adil, mematuhi aturan hukum dalam lehidupan masyarakat sebagai sebuah kesepakatan bersama. Sikap adil membawa orang lebih dekat ke taqwa, Ibn Miskawaih berpandangan bahwa sikap adil merupakan akumulasi dari nilai kebijaksanaan ( hikmah), nilai keberanian ( syaja'ah) dan nilai kelembutan ( iffah); Ketiga, nilai toleransi ( al-tasamuh) merupakan sikap seseorang terhadap keragaman agama, budaya, bahasa dan negara atau lainnya. Keragaman tersebut diterima sebagai sebuah fakta dan menghormati serta menghargai perbedaan yang ada sebagai bentuk keindahan dan rahmat dari yang M aha Kuasa. KH Ahmad Siddiq memformulasikan sikap toleran ini dalam prinsip-prinspi persaudaraan, yakni ukhuwah (persaudaraan) dalam konteks agama yang sama (ukhuwah Islamiyah), bangsa ( ukhuwah wathoniyah) yang sama, atau kemanusiaan (ukhuwah basyariyah) yang sama. Al-Quran surat al-Baqarah ayat 256 menunjukkan bahwa sikap toleransi merupakan perwujudan dari persaudaraan; Keempat, nilai reformatif ( al-ishlahiyah) yakni melakukan transformasi terus menerus menuju ke arah yang lebih baik (al-ishlah ila ma huwa al-ashlah). Kaidah al-muhafadhah 'ala al-qadim al-shalih wa alakhdzu bi al-jadid al-ashlah menjadi pedoman transformasi tersebut. Rahmatan lil 'alamin yang berarti Islam "damai", atau "cinta untuk universal" menjadi dasar dari transformasi dan kaidah tersebut sebagaimana terkandung dalam al-Q uran surat al-Anbiya' ayat 107; Kelima, nilai dinamis (al-tathowwur) merupakan respon seseorang terhadap perkembangan yang terjadi dengan mengkontekstualisasikan setiap permasalahn yang muncul. Sikap dinamis membawa seserang untuk melihat sesuatu tidak hanya secara materi tetapi apa yang ada di balikt itu, yakni situasi yang melartarbelakanginya. (Ali, 2019)

Makna hakiki dari Ahlussunnah Walj amaah -khususnya di Nahdhatul Ulamaadalah:"Ahlussunnah Waljamaah adalah paham yang menganut ajaran dari salah satu empat madzhab di bidang fiqih. Di bidang tauhid, menganut ajaran Imam Abu $\mathrm{H}$ asan al-Asy'ari dan Imam Abu M ansur al-M aturidi. Di bidang tasawuf menganut dasar-dasar ajaran Imam Q asim al-Junaidi ( M uhibbin, 2010).

Adapun Pendidikan karakter berbasis nilai ahlussunnah waljamaah seharusnya mempertimbangkan perlunya memasukkan civic values(nilai-nilai kewarganegaraan) dalam kegiatanpembelajaran sehingga mampu mencetak output yang mempunyaikesadaran moderat dan multikultural.Pada gilirannya mereka mampumenerapkan sikap sikap yang telah dimiliknya dalamkehidupan sehari-hari.Berbagaikomponen yang terlibat dalam proses pendidikan perlu terlebih dahulu direncanakan sedemikian rupa agar dapat mendukung terwujudnya gagasan tersebut.F aktor penting yang menjadi sorotan dalam hal ini adalah faktor kurikulum, pendidik, dan strategi pembelajaran yang digunakan pendidik. M enunjuk prioritas 
tersebut bukan berarti bahwa faktor lain kurang penting, namun ketiga hal tersebut merupakan prioritas yang perlu diperhatikan ( M uqowim, 2004; Purnama, 2018).

Untuk selanjutnya, Internalisasi nilai-nilai karakter berbasis nilai-nilai ahlussunnah Waljamaah pada MTs Ma'arif NU Kemiri, sebagai sebuah proses peembentukan mental pada anak didik, mengikuti pendapat $M$ aragustam yang membagi strategi pembentukan mental menjadi lima tahapan. Yaitu Rukun pertama. Moral acting (tindakan moral) dengan pembiasaan dan pembudayaan nilai-nilai kebajikan moral. $\mathrm{H}$ al ini didasarkan pada hadits $\mathrm{N}$ abi yang memerintahkan orang tua untuk memerintahkan anak melaksanakan sholat pada umur 7 tahun dan pada usia 10 tahun boleh memukulnya. H adits ini menunjukkan pembiasaan agar anak dlm tiga sejak umur 7 tahun sampai 10 tahun memiliki karakter ketaatan pada Allah. Dengan demikian tidak diperlukan lagi pemukulan karena sudah terbentuk karakter untuk selalu melaksanakan shalat.

Rukun Kedua. Moral knowing (pengetaahuan tentang nilai-nilai kebajikan moral). Memberikan pengetahuan tentang nilai-nilai kepada anak didik. Rukun ketiga. Moral feeling dan loving (merasakan dan mencintai pengetahuan nilai-nilai kebajikan moral). M emberikan kesadaran dan memotivasi untuk mencintai sebuah amal baik. Rukun keempat. Keteladanan ( uswah hasanah- role modeling) dari lingkungan sekitar, terutama para guru dan pendidik. Karena uswah lebih mudah untuk ditiru oleh anak didiknya. Dan Rukun kelima, Tobat non akademik dan akademik dengan melaksanakan takhalli, tahalli, dan tajalli. Takhalli dimaksudkan mengosongkan hati dari karakter yang tidak baik, tahalli dimaksudkan mengkondisikan hati untuk menyiapkan diri mengisinya dengan karakter yang baik, dan tajalli dimaksudkan mengisi hati dengan karakter yang baik atau disebut pula akhlak al-karimah (akhlak yang mulia) (M aragustam, 2011; N aiyya Balaya \& Zafi, 2020).

\section{Penerapan pendidikan karakter berbasis nilai-nilai ahlussunnah waljamaah di MTs NU Ma'arif Kemiri}

Berdasarkan hasil pengamatan, dokumentasi dan wawancara penulis dengan semua komponen pendidikan MTs Ma'arif NU Kemiri, dapat penulis gambarkan bahwa MTs Ma’arif N U Kemiri memiliki beberapa langkah yang terdiri dari perencanaan, pelaksanaan dan evaluasi pendidikan karakter berbasis nilai A hlussunnah Waljamaah sebagai berikut:

\section{a. Perencanaan}

MTs Ma'arif NU Kemiri menyusun perencanaan pendidikan karakter berbasis nilai ahlussunnah waljamaah secara terencana dan terstruktur. dapat dilihat dari adanya rencana 
strategis, rencana tahunan sebagaimana terlihat pada kurikulum Tingkat Satuan Pelajaran (KTSP) yang disusun setiap tahun. Penyusunan KTSP ini disamping melibatkan seluruh steakholder yang ada di MTs juga diselenggarakan secara demokratis, juga selalu mengedepankan nilai-nilai ahlussunnah waljamaah, yakni: pertama, tawasuth, mengambil jalan tengah, tidak bersifat ekstrim dalam merencanakan kegiatan-kegiatan pendidikan dan menetapkan materi yang akan disampaikan. Ada penelaahan terlebih dahulu terhadap setiap materi yang akan diambil dalam silabus kurikulum, khsusnya pada muatan lokal. Sehingga muncullah muatan lokal pembelajaran $\mathrm{Ke}$-N U -an yang menitik beratkan pada tiga pilar qonun asasinya KH Hasyim Asy'ari, yakni di bidang Teologi mengikuti asy'ariyah dan maturidiyah, di bidang fiqih mengikuti empat madzhab (Imam Khanafi, Imam Maliki, Imam Syafi'i dan Imam H ambali) dan di bidang tasawuf mengikuti I mam al-G hazali atau AlJunaidi (A rif, 2018).

kedua, i'tidal, bersikap adil dalam menentukan sikap dan menempatkan segala sesuatu pada tempatnya. M isalnya pada penentuan tata tertib madrasah yang proporsional dalam menyelesaikan setiap permasalahan yang muncul. Beberapa peristiwa terjadi di MTs NU Ma'arif dapat diselesaikan dengan baik oleh pihak sekolah dan menemukan win-win solution, tidak berpihak pada kepentingan citra sekolah ataupun orang tua siswa, tetapi betul betul secara adil mengambil langkah penyelesaian yang adil dari pandangan kedua belah pihak; Ketiga, Tasammuh. Perumusan perencanaan pendidikan karakter di MTs Ma'arif NU Kemiri selalu mempertimbangkan keragaman pemahaman dan latar belakang siswa maupun guru yang berproses di M adrasah, sehingga dihasilkan rumusan perencanaan yang memahami perbedaan dan tepat dalam bingkai kesepakatan bersama. D alam perencanaanya, pertimbangan peluang sebagai bagian dari analisis SWOT yang dibuat memperhatian sekeliling madrasah adalah masyarakat yang religius dan toleran memperkuat I slam wasathiyah; dan keempat, ishlahiyyah, penyusunan perencanaan bersifat adaptif terhadap perkembangan dan pada giliranya melahirkan perubahan yang ditujukan ke arah yang lebih baik. Menurut keterangan $\mathrm{KH}$. Achmad Hamid AK, S.Pd.I, praktisi pendidikan di MTs Ma'arif NU Kemiri, perencanaan berupa penyusunan KTSP dilakukan setiap tahun. $\mathrm{H}$ al ini dilakukan agar setiap tahun dilakukan evaluasi dan revisi jika dibutuhkan. Evaluasi dan Revisi dilakukan untuk memenuhi tuntutan perkembangan yang terjadi baik perkembangan yang terjadi dalam internal $M$ adrasah maupun perkembangan yang terjadi di luar M adrasah. M engikuti perkembangan (ishlahiyyah) merupakan salah satu prinsip dalam ahlussunnah waljamaah yakni bersifat reformatif (ishlahiyyah) menuju kepada yang lebih baik secara terus menerus ( al-ishlah ila ma huwa alashlah) (N urkilat, 2021). Pemikiran ishlahiyah ini membuka jalan bagi tidak adanya stagnasi dalam mengikuti nilai-nilai Ahlussunnah waljamaah ketika ahlussunnah waljamaah diposisikan sebagai jalan berfikir ( fikroh manhajiyah) Kelima. Tathowwur atau dinamis. MTs Ma'arif NU 
Kemiri mengikuti kondisi zaman dan lingkungan saat ini. Sikap dinamis ini ditujukkan dengan melakukan kerjasama dengan berbagai pihak antara lain: komite Madrasah yang terdiri dari wali murid dan tokoh pendidikan setempat. Tugas Komite adalah merencanakan dan melaksanakan pengembangan pendidikan di M T s M aarif N U Kemiri meliputi pengembangan sarana prasarana, pengembangan budaya akademi dan penanaman nilai yang dalam hal ini berpusat pada penanaman nilai-nilai ahlussunnah waljamaah; Pondok pesantren sekitar Madrasah. Ada 4 Pondok pesantren yang berdiri di lingkungan Madrasah. Setiap siswa diharapkan mengikuti pembelajaran di pondok pesantren tersebut dan khusus untuk siswa baru atau pindahan dari luar Madrasah diwajibkan mengikuti pondok pesantren untuk mengupgrade kemampuanya agar sam adengan siswa yang lain; Takmir M asjid Desa sekitar sebagai sarana pembauran siswa dengan kegiatan keagamaan di tengah-tengah masyarakat. Menurut Suparno, SPd, Kepala MTs Ma'arif NU Kemiri, menghadirkan dinamika yang ada di masayarakat menjadi bagian dari pengembangan Madrasah agar siswa mampu memahami setiap perkembangan masyarakat dan menyikapinya secara baik..

\section{b. Pelaksanaan}

Thomas Lickona mengenalkan pendidikan karakter melalui tiga aspek yang perlu diketahui yakni: memahami etika ( moral knowing) mewujudkan karakter ( moral action) dan naluri moralitas ( moral feeling) (Putri et al., 2020). Tiga aspek ini dirasakan kurang karena dalam pelaksanaan di lapangan membutuhkan tambahan yang sesuai dengan karakteristik masyarakat Islam. O leh karena itu, pelaksanaan pendidikan karakter berbasis Ahlussunnah waljamaah di MTs Ma'arif NU Kemiri Purworejo dilakukan dengan menanamkan nilai-nilai Ahlussunnah Waljamaah kepada siswa melalui tahapan secara berurutan sebagai sebuah strategi yang mengacu pada teori M aragustam dalam pendidikan karakter, sebagai berikut.

Tindakan moral (Moral acting) dengan melakukan pembiasaan dan pembudayaan nilai-nilai kebajikan moral. MTs Ma'arif NU mengembangkan pembiasaan: (a) Melafalkan asmaul husna dan doa belajar serta ikrar sebagai muslim pada awal pembelajaran di pagi hari, D engan pembiasaan ini, siswa lambat laun hafal dan meresapi makna kalimat yang diucpakan setiap hari tersebut untuk membimbing hati yang selalu dekat dengan nilai-nilai keimanan dan keislaman. (b) Sholat berjamaan di Masjid kampung sekitar Madrasah. Pembiasaan ini membimbing siswa untuk disiplin dalam melaksanakan sholat lima waktu secara lengkap sesuai syarat, rukun dan sunnahnya sebagaimana yang diajarkan para U lama yang bersanad sampai ke $N$ abi SAW. (c) M ushafahah (bersalaman) dengan guru ketika hendak masuk ruangan kelas setelah mengikuti apel. Pembiasaan ini berlaku pada saat bembelajaran tatap muka, tentu dengan tetap mengikuti protokol kesehatan mengingat masa pandemi, dan karenanya 
bersalaman tidak menyentuhkan tangan, tetapi cukup dengan menganggukkan kepala dan memberikan tanda hormat dengan tangan dirapatkan di depan dada. Pembiasaan ini dimaksudkan untuk menguatkan rasa penghormatan siswa terhadap pendidikan sekaligus terhadap ilmu yang akan diberikan kepada mereka dari para gurunya, dengan demikian akan terwujud ilmu yang manfaat. (d) Penggunaan bahasa jawa yang baik dalam kegiatan di luar pembelajaran di kelas. Pembiasaan bahasa jawa yang baik ini memberikan pelajaran pada siswa untuk berakhlaqul karimah yang ditunjukkan dengan penggunaan tingkatan bahasa, krama kepada guru dan orang yang lebih tua menunjukkan penghormatan, madyo atau ngoko kepada sesama atau yang lebih muda sebagai bentuk kedekatan dan kasih sayang. Pembiasaan ini harus dilakukan sejak dini dan dalam waktu yang terus menerus (W elas2, 2019).

Pengetahuan tentang nilai-nilai kebajikan moral (Moral knowing). MTs Ma'arif NU Kemiri memberikan pengetahuan tentang nilai-nilai kepada anak didik melalui: (a) Pembelajaran yang mengintegrasikan pelajaran materiumum dengan nilai-nilai agama. M isalnya dalam memberikan pembelajaran biologi tentang makhluk hidup (biotik) maupun tidak hidup (abiotik). M enurut penjelasan Mansyur SPd, guru MTs Ma’arif NU Kemiri, pada saat pembelajaran biologi, guru mengenalkan prinsip ketauhidan kepada siswa bahwa semua makhluk pasti ada yang menciptakan (al-Kholik) dan keberadaan al-Kholiq pasti M aha Esa karena pasti mempunyai otoritas tunggal dalam penciptaan segala makhluknya tersebut. (b) $\mathrm{M}$ ateri Ke-N U-an meliputi: pengetahuan tentang dasar-dasar dan nilai-nilai ke N $\mathrm{U}$-an, yakni Ahlussunnah waljamaah an-nahdliyah dan pemahaman tentang amaliyah-amaliyah warga NU. M engetahui pilar ahlussunnah waljamaah an-nahdliyah, yakni di bidang Teologi mengikuti asy'ariyah dan maturidiyah, di bidang fiqih mengikuti empat madzhab (Imam Khanafi, Imam Maliki, Imam Syafíi dan Imam Hambali) dan di bidang tasawuf mengikuti Imam al-Ghazali atau AlJ unaidi ( Arif, 2018)

M erasakan dan mencintai pengetahuan nilai-nilai kebajikan moral ( $M$ oral feeling dan (oving). Memberikan kesadaran dan memotivasi untuk mencintai sebuah amal baik. MTs Ma'arif NU Kemiri mengembangkan moral feeling dengan beberapa kegiatan antara lain: (a) M ushafahah (bersalaman) dengan guru, pada saat pandemi hanya menganggukkan kepala dan merapatkan tangan di depan dada. Kegiatan ini merupakan bentuk internalisasi nilai kecintaan kepada guru sebagai pendidik yang memiliki ilmu dan ilmu itu sendiri yang akan disampaikan oleh guru kepada siswanya. M enurut Ibnu K haldun pembelajaran agama akan lebih efektif jika dilakukan dengan adanya tatap muka dan kecintaan siswa terhadap ilmu dan pemilik ilmunya yaitu guru. (b) Gerakan infak setiap hari jumat yangdikumpulan dari siswa dan guru. Infak ini dimanfaatkan untuk santunan sosial, berbagi pada siswa yang sakit, membutuhkan dan anak 
yatim. Dengan gerakan ini memberikan penanaman tentang cinta sesama dan peduli pada kelemahan dan penderitaan orang lain. Di sini diajarkan pula tentang sikap baik menghormati dan kasih sayang kepada orang lain dengan menjaga diri dari perbuatan yang tidak menyenangkan, lisan berupa gunjingan dan bulying, serta sikap permusuhan dan ketidak sukaan.

Keteladanan ( uswah hasanah / role modeling) dari lingkungan sekitar, terutama para guru dan pendidik. Karena uswah lebih mudah untuk ditiru oleh anak didiknya. MTs Ma'arif NU Kemiri memberikan keteladanan langsung dari pimpinan M adrasah dan para guru sebagai pola sikap yang mudah ditiru oleh para siswanya, antara lain: (a) Berkata yang halus, dalam penggunaan bahasa jawa selain dalam pembelajaran tatap muka yang berbahasa Indonesia. Bahasa jawa yang diguanakan disesuaikan dengan unggah-ungguh dan rakit bahasa yang semestinya. Pelaksanaan ini sejalan dengan pola pendidikan karakter melalui sopan santun yang dapat mempecepat pengembangan pendidikan karakter sopan santun (Imran, Rustiyarso, 2019). Dan secara umum sejalan dengan salah satu nilai ahlussunnah waljamaah yakni tasammuh. (b) Tingkah laku pimpinan madrasah dan guru selalu dipantau dan pembinaan agar memberikan contoh yang baik dalam bersikap di manapun berada, karena siswa akan bertemu gurunya di masa pembelajaran dalam kelas dan dalam kehidupan sehari-hari. T eladan dari perbuatan yang baik seorang guru mutlak dilakukan.

Tobat non akademik dan akademik dengan melaksanakan takhalli, tahalli, dan tajalli. MTs Ma'arif NU Kemiri mengembangkan internalisasi nilai ahlussunnah waljamaah malui tahap ini dengan menyelenggarakan: (a) Ziarah qubur para pendiri Madrasah dan penyebar agama Islam di wilayah Purworejo. Kegiatan ini dilaksanakan minimal 2 kali dalam setahun yakni pada awal pembelajaran dan pada saat menjelang ujian akhir. Dalam prosesi ziarah ini dikenalkan konsep pengosongan diri dari segala sifat yang tidak baik dengan mengingat kematian yang mengakhiri segala perbuatan baik manusia sekaligus mengakhir kejelekannya. Dengan demikian muncul kesadaran untuk senantiasa siap menghadapi kematian yang tidak diketahui kapan waktunya dengan senantiasa membersihkan hati. Kemudian menyiapkan hati yang sudah bersih dari sifat yang tidak baik itu dengan mengelola hati yang lembut akibat dari mengingat kematian dan siap menerima pengelolaan hati berikutnya. T erakhir mengisi hati dengan sifat-sifat yang mulia yakni memenuhi hati yang sudah bersih dan siap dimasuki sifatsifat akhlak muli. Dalam ziarah ini dikenalkan tentang kebaikan dan akhlak mulia tokoh yang diziarahi sehingga tetap dikenang kebaikannya sebagai motivasi bagi siswa untuk senantiasa mengisi hati dengan sifat dan perbuatan yang baik. (b) Mujahadah atau istighotsah, yakni bersungguh-sungguh memohon kepada Allah SWT melalui pembacaan ayat suci al-quran 
utamanya surat yasin, dzikir, istighfar, sholawat dan doa yang disebut dengan tahlilan. D engan mujahadah ini dilakukan pembersihan hati melalui istighfar. Dua kegiatan ini sangat mendukung pengembangan karakter melalui keterampilan. Salah satu keterampilan yang perlu dilakukan adalah keterampilan spiritual yang pada intinya mengajarkan bersyukur dan berdoa menuju ridlo Ilahi ( T ua \& Remaja, 2015).

\section{c. Evaluasi}

Evaluasi pendidikan karakter berbasis nilai ahlussunnah waljamaah di MTs Ma'arif NU Kemiri dilakukan dalam beberapa tahap. Tahap pertama dilakukan pada tingkat satuan pelajaran ketika pembelajaran selesai, tes ini berupa pre test dan post tes yang dilakukan secara lisan maupun tertulis. Tahap kedua, pada saat materi suatu bahan pelajaran selesai dilaksanakan melalui tes tengah semester dan tes akhir semester. T ahap ketiga evaluasi akhir madrasah yang dijadikan pedoman pengukuran sejauh mana tingkat pemahaman siswa terhadap materi nilai-nilai ahlussunnah waljamaah diserap.

Di samping itu, selain pengetahuan siswa di atas, prilaku siswa juga menjadi bahan evaluasi. Evaluasi ini dilakukan melalui pengamatan terhadap prilaku siswa sampai sejauh mana siswa dapat menunjung tinggi nilai ahlussunnah waljamaah ( tawassuth, i'tidal, tasammuh dan ishlahiyyah). N ilai-nilai ini menjadi ruh dalam penentuan tata tertin belajar di MTs Ma'arif NU Kemiri dan dari tata tertib inilah standar penilian prilaku siswa dilakukan. Sehingga penilaian dapat dilakukan secara menyeluruh dan memenuhi unsur nilai ahlussunnah waljamaah tersebut.

\section{Simpulan}

Pendidikan karakter berbasis nilai ahlussunnah waljaamaah di MTs Ma'arif NU Kemiri Purworejo dilakukan dengan menanamkan nilai-nilai ahlussunnah waljamaah yakni tawassuth (jalan tengah), i'tidal (adil), tasammuh (toleran) dan ishlahiyyah (reformatif). Penanaman nilai ini dilaksanakan secara menyeluruh sejak perencanaan, pelaksanaan dan evaluasinya. Ditemukan fakta bahwa pendidikan karakter berbasis nilai ahlussunnah waljamaah di MTs Ma'arif NU Kemiri Purworejo dilaksanakan seacara berurutan melalui strategi pembiasaan, pengenalan pengetahuan kebaikan, pengenalan kecintaan pada kebajikan, uswah hasanah, dan pertobatan akademik maupun non akademik.

\section{DAFTAR PUSTAKA}

Abdulloh, H . (2017). Pendidikan Karakter Berbasis Pesantren, Pelajar dan Santri dalam Era IT dan Cyber Culture, I Imtiyaz. 
Abdusysyukur, A.-S. S. A. F. bin. (n.d.) . al-K awakib al-Lama' ah. Karya T oha Putra.

Ali, M . (2019). The Interrelationship of Indonesia-C hina-India in Religion from A rabian I slam to N usantara I slam, Proceding of the International Seminar and Confrence 2015: The Golden Triagle (Indonesia-India-Tiongkok) Interreliations in Religion, Science, C ulture, and $\mathrm{E}$.

Ambarwati, D . (2019) . Kasus AY cerminan boborknya moral generasi. Republika.C o.Id.

Amirudin Yoyok. (2017). Pendidikan Karakter Berbasis Aswaja. Vicrotina U nisma, 2 nomor 2, 110.

Anam, F. K., Padil, M ., \& Yahya, M . (2021). Building Ahlus-Sunnah wal-Jamaah an-N ahdliyah Character as the Pillar of Islamic Moderation in Islamic Boarding School. Buletin AlTuras, 27(2), 249-264.

Andayani, A . M . dan D . ( 2011) . Pendidikan Karakter Persepektif I slam. Rosdakarya.

Ari, N . M . (2019). Ahlu as-sunnah wa al-jama'ah Sejarah DinMoch. Ari Nasichuddin, Ahlu assunnah wa al-jama'ah Sejarah Dinamika Umat Islam Dan Analisis Sosial.

Arif, M . (2018). Revitalisasi Pendidikan A swaja an N ahdliyah (Ke-N u-an) Dalam M enangkal Faham Radikalisme Di Smk AI-Azhar M enganti Gresik. J-PAI: Jurnal Pendidikan Agama Islam, 5(1) , 15-25. https:/ / doi.org/ 10.18860/ jpai.v5i1.6052

Fatkhur, R. (2019). Nilai-N ilai Pendidikan Anti Bulying Dalam Sunnah Dan Kontekstualisasinya Bagi Pendidikan Karakter. Program D oktor U IN W alisongo.

H ariyanto, S. M . dan. (2011). Konsep dan M odel Pendidikan Karakter. PT Remaja Rsdakarya. H eri, G. (2012) . Pendidikan Karakter Konsep dan Implementasi. Alfabeta.

Hidayah, N. (2015). Redefinisi Ontologi Aswaja Dalam Pendidikan Ma'Arif Di Era Kontemporer. Edukasia: Jurnal Penelitian Pendidikan Islam, 10(1), 105-124. https:// doi.org/ 10.21043/ edukasia.v10i1.787

Imran, Rustiyarso, S. (2019). Pengembangan Karakter Sopan Santun Siswa Di Man 1 M empawah. Jurnal Pendidikan D an Pembelajaran K hatulistiwa, 8(3) , 1-11.

Juli H antoro, E. (2021) . 6 Pendekatan Cegah Kekerasan Pelajar M enurut Ketua DPRD Kota Bogor. Tempo.

Lickona Thomas. (2015) . C haracter M atters, Persoalan Karakter (W. dan S. U yu ( ed.)) . Bumi A ksara.

M aragustam. (2011). Pembentukan karakter anak bangsa, perspektif filsafat pendidikan Islam. Pasca Sarjana FT IK UIN Sunan Kalijaga.

M uhammad, A. (2011). Pendidikan Agama I slam. Rosdakarya.

M uhammad, W . A . ( 2012) . M endamaikan A hlus As-sunnah di N usantara,. Pustaka Al-Kautsar. 
M uhibbin, Z. A. (2010). Pemikiran KH . M. H asyim Asy'ari Tentang Ahl al-As-sunnah Wa alJama'ah. Khalista.

M uqowim. (2004). M encari Pola Pendidikan Agama. Perspektif M ultikultural, I (3) T ahu, 8.

Naiyya Balaya, A., \& Zafi, A. A. (2020). Peranan Kearifan Dalam Pembentukan Karakter Peserta Didik. Journal of Civics and Education Studies, 7(1), 27-34. http:/ / openjournal.unpam.ac.id/ index.php/ PKn/ article/ view/ 4791

Nurkilat, A. (2021). PEN GUATAN N ILAI-NILAI ASWAJA ALA KIAI HASYIM ASY'ARI DALAM PENDIDIKAN KONTRA-RADIKALISME. MIYAH Jurnal Studi Islam, 17, 39-64.

Pangwijaya, S. (2019). Kasus terkait Krisi M oral. Kompasiana.

Penyusun, T. (2011). Bahan Pelatihan Penguatan M etodologi Pembelajaran Beradasarkan N ilai-niliai budaya untuk membentuk daya saingdan karakter bangsa.

Purna Siswa Aliyah. (2007). Madrasah Hidayatul Mubtadi-ien. Polaritas Sektarian, Rekonstruksi Doktrin Pinggiran. Lirboyo Press.

Purnama, S. (2018). Pengasuhan Digital untuk Anak Generasi Alpha AH -PIECE. Al H ikmah Proceedings an I slamic Early C hildhood Education, 1(April) , 493-502.

Putri, B. A., Putri, L. A., \& O viensy, V. (2020). ROLE OF THE FAM ILY IN FO RM ATION OF CHILDREN CHARACTERS BASED. Jurnal Tunas Cendekia, 3, Edisi 1, 97.

Siska N irmala, E. (2019). sepanjang 2019 KPAI terima 153 aduan kekerasan fisik terhadap siswa. Pikiran Rakyat.

Subaidi. (2019). Pendidikan Karakter Berbasis Aswaja di MA Amsilati Bangsri Jepara. JASN A;A swajaStudies, 1(1), 34-46.

Syamsul, K. (2013). Pendidikan Karakter: Konsepsi dan Implementasi di Lingkungan Keluarga, sekolah, Perguruan T inggi dan M asyarakat. Ar-Ruz M edia.

Tua, O., \& Remaja, S. (2015). Pembentukan Karakter Remaja M elalui Keterampilan Hidup. Jurnal Pendidikan Karakter, 2, 120581. https:// doi.org/ 10.21831/jpk.v0i2.8618

Welas2, P. U. (2019). PENANAMAN NILAI KARAKTER MELALUI PEMBIASAN BERBAHASA JAWA PADA ANAK USIA DINI DI DESA TANGGERAN, KABU PATEN BAN YU MAS. Vembria Rose H andayani1, N indya Putri Pratama, 7(2), 28-35.

Wibowo, A. A., N ur, M . E., \& Karim, M . A. (2018). IN TERN ALISASI NILAI PEN DIDIKAN KARAKTER ASWAJA (Stusi Analisis Aktivasi N ilai-nilai Keaswajaan). Manarul Qur'an: Jurnal IImiah Studi Islam, 18(2), 4-20. https:/ / doi.org/ 10.32699/ mq.v18i2.937

Zubaedi. (2011). Desain Pendidikan Karakter Konsepsi dan Aplikasinya dalam Lembaga Pendidikan. Kencana. 
